Jurnal Ilmu Pertanian Agronitas Vol. 1 No.2 Edisi Oktober 2019

\title{
PENAMPILAN PADI VARIETAS INPARI DI RAWA LEBAK DESA PEMULUTAN ULU KABUPATEN OGAN ILIR PROVINSI SUMATERA SELATAN
}

\author{
Appearance Of Paddy Inpari Variety In Lebak Swamp Desa Pemulutan Ulu \\ Ogan Ilir Regency, South Sumatra Province
}

\author{
$\underline{\text { Suparwoto }}^{*}$ ), Joni Karman, Waluyo ${ }^{1}$ ) \\ 1)Balai PengkajianTeknologi Pertanian Sumatera Selatan \\ Jl. Kol. H.Burlian KM 6 no. 83 Km 6 Palembang \\ *Penulis untuk korespondensi: suparwoto11@gmail.com
}

\begin{abstract}
ABSTRAK
Kegiatan ini dilaksanakan di Desa Pemulutan Ulu, Kecamatan Pemulutan, Kabupaten Ogan llir (OI), Sumatera Selatan, pada April-Agustus 2019. Adapun tujuan untuk mendapat varietas Inpari yang adaptif dan mempunyai potensi hasil tinggi. Bahan yang dibutuhkan antara lain : benih padi varietas Inpari 6, Inpari 33, Inpari 34 dan Situbagendit, pupuk urea, SP-36, KCl, pestisida, herbisida dan terpal. Selain itu alat yang dibutuhkan antara lain : hand traktor, meteran, timbangan, parang, cangkul, sprayer. Metode yang digunakan pengamatan langsung di lapangan, luasan pengkajian 4 hektar. Pupuk yang digunakan $150 \mathrm{~kg}$ Urea, $100 \mathrm{~kg}$ SP-36 dan $100 \mathrm{~kg} \mathrm{KCl} / \mathrm{ha}$ sesuai anjuran. Pemupukan dilakukan 2 kali yaitu pada umur 1 minggu setelah tanam (MST) dengan takaran $75 \mathrm{~kg}$ urea, $100 \mathrm{~kg} \mathrm{SP-36} \mathrm{dan} 100 \mathrm{~kg}$ $\mathrm{KCl} / \mathrm{ha}$ dan pada umur 4 minggu setelah tanam (MST) dengan takaran $75 \mathrm{~kg}$ urea/ha. Sistem tanam tegel jarak tanam $25 \times 25 \mathrm{~cm}$. Data yang dikumpulkan meliputi: tinggi tanaman saat panen, jumlah anakan produktif/rumpun, panjang malai, jumlah gabah per malai, jumlah gabah isi per malai, dan produksi gabah konversi per hektar. Metoda yang digunakan adalah pengamatan langsung di lapangan (observasi) terhadap varietas unggul yang diperagakan. Data yang diperoleh disusun secara tabulasi dan dianalisis dengan uji statistik yaitu uji kesamaan nilai tengah (uji-t). Analisis data dilakukan dengan program SPSS. Hasil menunjukkan bahwa Inpari 6,Inpari 33, Inpari 34 dan Situbagendit dapat beradaptasi di rawa lebak dengan tinggi tanaman tergolong pendek dan jumlah anakan produktif per rumpun tergolong banyak dengan produksi rata-rata 7,4 ton GKP/ha dimana produksi gabah tertinggi dicapai oleh Situbagendit (8,7 ton GKP/ha) diikuti oleh Inpari 34 (8,0 ton GKP/ha), Inpari 6 (7,5 ton GKP/ha) dan Inpari 33 (5,4 ton GKP/ha). Tekstur nasi Inpari 6 (sangat pulen), Inpari 33 (sedang), Inpari 34 (agak pera) dan Situbagendit (pulen). Varietas tersebut dapat dikembang di rawa lebak tengahan.
\end{abstract}

Kata kunci: Penampilan, rawa lebak, varietas unggul padi

\begin{abstract}
This activity was carried out in Pemulutan Ulu Village, Pemulutan District, Ogan llir Regency (OI), South Sumatra, in April-August 2019. The aim was to obtain adaptive Inpari varieties with high yield potential. Materials needed include: rice seed varieties Inpari 6, Inpari 33, Inpari 34 and Situbagendit, urea fertilizer, SP-36, KCl, pesticides, herbicides and tarpaulins. In addition, the tools needed include:
\end{abstract}


hand tractor, meter, scale, machete, hoe, sprayer. The method used is direct observation in the field, the assessment area is 4 hectares. The fertilizer used is $150 \mathrm{~kg}$ Urea, $100 \mathrm{~kg} \mathrm{SP}-36$ and $100 \mathrm{~kg} \mathrm{KCl} / \mathrm{ha}$ as recommended. Fertilization is done twice, namely at the age of 1 week after planting (MST) with a dose of $75 \mathrm{~kg}$ urea, $100 \mathrm{~kg} \mathrm{SP}-36$ and $100 \mathrm{~kg} \mathrm{KCl} / \mathrm{ha}$ and at the age of 4 weeks after planting (MST) at a dose of $75 \mathrm{~kg}$ urea / ha. Tiles planting system spacing $25 \times 25 \mathrm{~cm}$. Data collected includes: plant height at harvest, number of productive tillers, panicle length, number of grains per panicle, number of filled grains per panicle, and production of converted grain per hectare. The method used is direct observation in the field (observation) of the superior varieties exhibited. The data obtained were tabulated and analyzed with a statistical test that is the similarity test of the middle value (t-test). Data analysis was performed with the SPSS program. The results show that Inpari 6, Inpari 33, Inpari 34 and Situbagendit can adapt in the lebak swamp with relatively high plant height and the number of productive tillers per family is classified as many with an average production of 7.4 tons GKP / ha where the highest grain production is achieved by Situbagendit ( 8.7 tons of GKP / ha) followed by Inpari 34 (8.0 tons of GKP / ha), Inpari 6 (7.5 tons of GKP / ha) and Inpari 33 (5.4 tons of GKP / ha). Texture of Inpari 6 rice (very fluffier), Inpari 33 (moderate), Inpari 34 (slightly pera) and Situbagendit (fluffier). These varieties can be developed in the middle of the lebak swamp.

Keywords: Appearance, lebak swamp, superior varieties of rice

\section{PENDAHULUAN}

Tanaman padi merupakan salah satu tanaman pangan yang mendapat perhatian khusus dari pemerintah Indonesia karena sebagian besar rakyat makan beras sebagai makanan pokok. Penduduk Indonesia setiap tahun selalu bertambah maka harus diimbangi dengan peningkatan produksi beras. Peningkatan produksi beras dapat dilakukan secara ekstensifikasi maupun intensifikasi dengan mengoptimalkan lahan sub optimal diantaranya lahan rawa lebak yang ada di Provinsi Sumatera Selatan. Pada umumnya petani menanam padi hanya satu kali dalam setahun yaitu pada musim kemarau, penanaman padi dilakukan setelah air di rawa lebak dangkal mulai menyurut dan selanjutnya diikuti oleh lebak tengahan dan dalam. Di lahan lebak dalam biasa ditanami hanya menggunakan varietas lokal berumur dalam seperti varietas Pegagan, Siputih, Sawah Kanyut dan lainnya karena persemaian dilakukan dua sampai tiga kali baru bisa ditanam karena menyesuaikan tinggi permukaan air, bahkan kadang-kadang tidak bisa ditanami.

Produktivitas padi lahan rawa lebak dengan teknologi petani di Sumatera Selatan masih tergolong rendah yaitu berkisar 2,7-3,0 ton/ha (Suparwoto et al., 2016). Tingkat produktivitas tersebut masih rendah bila dibandingkan dengan potensi hasil dari beberapa varietas unggul baru padi yaitu 6-8 ton/ha (Jamil et al., 2016). Rendahnya produktivitas tersebut karena teknologi yang digunakan petani masih relatif sederhana, masih banyak penggunaan varietas lokal, varietas unggul tidak berlabel, dan penggunaan pupuk sangat tergantung dengan keadaan ekonomi petani serta penggunaan varietas yang sama dalam jangka waktu yang lama dan penurunan kualitas sumberdaya lahan (Suparwoto et al., 2017). Selain itu kendala di lahan rawa lebak di antaranya fluktuasi air yang cukup tinggi, yaitu banjir pada musim hujan dan kekeringan pada musim kemarau terutama pada lahan rawa lebak dangkal, prasarana pendukung 
belum memadai seperti jalan usahatani dan saluran drainase, terbatasnya modal usahatani (Suryana, 2016).

Penanaman varietas padi yang adaptif di lahan rawa lebak merupakan salah satu upaya penting yang perlu ditempuh sehingga produktivitasnya lebih tinggi karena varietas unggul merupakan salah satu paket teknologi efektif karena murah, mudah diabdopsi petani serta relatif tidak mencemari lingkungan (Abdullah et al., 2015). Dengan makin banyaknya varietas unggul yang dilepas, petani lebih banyak mempunyai pilihan akan varietas yang sesuai dengan keinginan dan spesifik wilayahnya. Hal ini akan memperluas keragaman genetik tanaman di lapangan sehingga dapat menekan resiko terjadinya ledakan hama dan penyakit tertentu

Berdasarkan hasil kajian sebelumnya bahwa varietas Inpari dapat beradaptasi di rawa lebak dengan produksi rata-rata 6 ton GKP/ha (Suparwoto, 2013). Dilaporkan oleh Waluyo et al. (2014), bahwa hasil yang dicapai oleh varietas Inpara 3, dan Inpar 4 rata-rata 3,0-3,6 ton GKP/ha lebih tinggi dari Ciherang $(2,7$ ton $\mathrm{GKP} / \mathrm{ha}$ ). Salah satu tahap dalam menghasilkan varietas unggul ialah melakukan uji multilokasi. Melalui pengujian ini diharapkan dapat diidentifikasi varietas-varietas yang memiliki daya adaptasi terhadap lingkungan tumbuh yang luas maupun lingkungan tumbuh spesifik dilihat dari aspek iklim, jenis tanah, kondisi cekaman biotik dan abiotik. Varietas unggul baru yang berkembang di petani diharapkan dapat diterima lebih cepat oleh konsumen bila sesuai dengan preferensi konsumen. Dari uraian di atas maka beberapa varietas Inpari dikaji di lahan rawa lebak Kabupaten Ogan Ilir dengan tujuan mendapat varietas Inpari yang adaptif dan mempunyai potensi hasil tinggi.

\section{METODE PENELITIAN}

Lokasi kegiatan di Desa Pemulutan Ulu, Kecamatan Pemulutan, Kabupaten Ogan Ilir, Sumatera Selatan pada April-Agustus 2019. Bahan yang dibutuhkan antara lain: benih padi, pupuk urea, SP-36, $\mathrm{KCl}$, pestisida, herbisida dan terpal. Alat yang dibutuhkan antara lain: hand traktor, meteran, tali jarak tanam, timbangan, parang, cangkul, sprayer. Varietas unggul yang diperagakan adalah 4 varietas yaitu Inpari 6, Inpari 33, Inpari 43, dan Situbagendit sebagai pembanding. Tanam pada bulan April 2019 seluas empat hektar. Pupuk yang diberikan sesuai anjuran $150 \mathrm{~kg}$ Urea, $100 \mathrm{~kg}$ SP-36 dan $100 \mathrm{~kg} \mathrm{KCl} / \mathrm{ha}$. Pemupukan dilakukan 2 kali yaitu pada umur 1 minggu setelah tanam (MST) dengan takaran $75 \mathrm{~kg}$ urea, $100 \mathrm{~kg}$ SP-36 dan $100 \mathrm{~kg} \mathrm{KCl} / \mathrm{ha}$ dan pada umur 4 minggu setelah tanam (MST) dengan takaran $75 \mathrm{~kg}$ urea/ha. Sistem tanam tegel jarak tanam $25 \mathrm{~cm} \times 25 \mathrm{~cm}$. Data yang dikumpulkan meliputi: tinggi tanaman saat panen, panjang malai, jumlah anakan produktif/rumpun, jumlah gabah per malai, jumlah gabah isi per malai, dan produksi gabah konversi per hektar. Hasil gabah diambil dengan ubinan $(2,5 x \quad 2,5 \quad m)$. Setiap parameter diambil 10 sampel tanaman dan hasil gabah diambil tiga kali ubinan. Metoda yang digunakan adalah pengamatan langsung di lapangan (observasi) terhadap varietas unggul yang diperagakan. Data yang diperoleh disusun secara tabulasi dan dianalisis dengan uji statistik yaitu uji kesamaan nilai tengah (uji-t). Analisis data dilakukan dengan aplikasi SPSS.

\section{HASIL DAN PEMBAHASAN}

\section{Tinggi tanaman saat panen}

Tinggi tanaman saat panen dari varietas Inpari 6, Inpari 33, Inpari 34 dan Situbagendit 
bervariasi dari $98,5 \mathrm{~cm}$ sampai $115,9 \mathrm{~cm}$. Berdasarkan uji statistic bahwa Inpari 6 berbeda sangat nyata dengan Inpari 34 dan Situbagendit tetapi tidak berbeda nyata dengan Inpari 33 . Sedangkan Inpari 33 berbeda sangat nyata dengan Inpari 34 tetapi tidak berbeda nyata dengan Situbagendit. Kemudian Inpari 34 berbeda sangat nyata dengan Situbagendit. Tanaman Inpari 6 mempunyai postur pendek $(98,5 \mathrm{~cm})$ sedangkan Inpari 34 mempunyai postur yang lebih tinggi $(115,9 \mathrm{~cm})$ dibandingkan dengan varietas lainya tetapi secara keseluruhan tergolong pendek kecuali Inpari 34 (Tabel 1). Perbedaan tinggi tanaman dari varietas yang dikaji sangat dipengaruhi oleh factor lingkungan dimana varietas tersebut ditanam dan factor keturunan dari masing-masing varietas. Tinggi tanaman merupakan parameter yang perlu diperhatikan karena dapat mengurangi hasil, bila terlalu tinggi maka akan berdampak tanaman tersebut rebah akibat kena angin kencang. Oleh sebab itu untuk di lahan rawa lebak dibutuhkan varietas yang mempunyai postur tanaman yang pendek dibawah $110 \mathrm{~cm}$. Tinggi tanaman Inpari 34 rata-rata $115,9 \mathrm{~cm}$, maka tanaman tersebut cenderung rebah sehingga biasanya kurang diminati petani. Dikatakan oleh Sution (2017) bahwa tinggi tanaman dapat berpengaruh terhadap panjang malai dan kerebahan sehingga akan berdampak pada penurunan hasil gabah. Selanjutnya dikemukakan oleh Asaad dan Warda (2011), bahwa tanaman yang tinggi tidak menjamin produksi tinggi.

Tabel 1. Rata -rata tinggi tanaman VUB di Desa Pemulutan ulu Kab.Ogan llir, 2019

\begin{tabular}{|c|c|c|c|c|}
\hline Varietas & Rata-rata & Inpari 6 & Inpari 33 & Inpari 34 \\
\hline Inpari 6 & 98,5 & - & & \\
\hline Inpari 33 & 103,8 & tn & - & \\
\hline Inpari 34 & 115,9 & ** & ** & - \\
\hline Situbagendit & 104,9 & ** & tn & ** \\
\hline Rata-rata & 105,7 & & & \\
\hline
\end{tabular}

\section{Jumlah anakan produktif/rumpun}

Jumlah anakan produktif/rumpun dari varietas yang dikaji juga bervariasi dimana jumlah anakan produktif dari 19,8-25,9 batang. Anakan produktif yang sedikit dicapai oleh Inpari $6(19,8$ batang), secara statistik berbeda tidak nyata dengan Inpari 33 dan Inpari 34 kecuali Situbagendit. Sedangkan anakan terbanyak dicapai oleh Situbagendit (25,9 batang). Jumlah anakan produktif Inpari 34 berbeda tidak nyata dengan Situbagendit (Tabel 2). Jumlah anakan produktif merupakan parameter yang berkolerasi positif terhadap peningkatan produksi. Jumlah anakan produktif yang banyak akan mendukung produksi gabah tinggi, tetapi jumlah anakan sangat dipengaruhi oleh faktor keturunan dan faktor lingkungan dimana varietas tersebut ditanam. Pada lingkungan yang kurang baik maka jumlah anakan akan berkurang seperti kekurangan air, lahan kurang subur, umur bibit tua akibat permukaan genangan air masih tinggi yang biasa terjadi pada rawa lebak. Perbedaan parameter pertumbuhan dan komponen hasil tanaman padi yang terdiri dari tinggi tanaman, jumlah anakan produktif, panjang malai, jumlah gabah per malai, jumlah gabah isi per malai dan umur panen dari varietas yang diuji disebabkan 
oleh faktor genetik dari masing-masing varietas dan faktor lingkungan dimana varietas tersebut ditanam (Wibawa dan Rahman, 2016, Handoko et al., (2017),). Kemudian IRRI (2009) dalam Manurung et al. (2017) membagi jumlah anakan produktif dengan lima kreteria yaitu sangat sedikit ( $<5$ anakan per tanaman), sedikit (5-9 anakan per tanaman), sedang (10-19 anakan per tanaman), banyak (20-25 anakan per tanaman) dan sangat banyak (>25 anakan per tanaman). Berdasarkan kriteria tersebut maka jumlah anakan dari varietas yang dikaji tergolong banyak. Dikemukakan Sugeng (2001) dalam Rois et al (2017) bahwa faktor yang mempengaruhi pembentukan anakan adalah jarak tanam, pupuk, varietas dan musim tanam. Jarak tanam yang lebar didukung dengan lingkungan yang sesuai diantaranya kesuburan tanah akan menghasilkan anakan yang banyak. Selanjutnya Ismunadji et al. (1988) dalam Manurung et al. (2017) menyatakan bahwa jumlah anakan ditentukan oleh radiasi matahari, unsur hara, ketersediaan air dan cara budidaya.

Tabel 2. Rata -rata jumlah anakan produktif VUB di Desa Pemulutan ulu Kab.Ogan Ilir, 2019

\begin{tabular}{lcccc}
\hline Varietas & Rata-rata & Inpari 6 & Inpari 33 & Inpari 34 \\
\hline Inpari 6 & 19,8 & - & & \\
Inpari 33 & 20,0 & tn & - & - \\
Inpari 34 & 23,8 & tn & tn & tn \\
Situbagendit & 25,9 & $* *$ & $* *$ & \\
Rata-rata & 22,3 & & & \\
\multicolumn{2}{l}{ Keterangan : ${ }^{* *}=$ berbeda sangat nyata (Probabilitas $\left.<0.01\right)$} &
\end{tabular}

\section{Panjang malai}

Panjang malai dari ke empat varietas yang dikaji bervariasi antara $23,3 \mathrm{~cm}-27,5 \mathrm{~cm}$, dimana malai terpendek dicapai oleh Inpari 6 $(23,3 \mathrm{~cm})$ dan secara statistik tidak berbeda nyata dengan Inpari 33, berbeda sangat nyata dengan Inpari 34 dan berbeda nyata dengan Situbagendit. Panjang malai terpanjang dicapai oleh Inpari 34 $(27,5 \mathrm{~cm})$ berbeda tidak nyata dengan Situbagendit. Kemudian Inpari 33 tidak berbeda nyata dengan Inpari 34 dan Situbagendit (Tabel 3). Panjang malai dari suatu varietas menjadi perhatian petani maka panjang dan pendeknya malai juga menentukan produksi. Malai yang panjang diharapkan mempunyai gabah yang banyak dibandingkan malai yang pendek. Dikemukakan oleh Siregar et al., (1988) dalam Waluyo et al., (2015) bahwa panjang malai juga merupakan parameter pendukung untuk memperoleh hasil yang tinggi. Panjang atau pendek suatu malai dari varietas yang ditanam tergantung pada kondisi lingkungan dan sifat genetik dari varietas (Norsalis, 2011) dalam Handoko et al.(2017).

Tabel 3. Rata-rata panjang malai VUB di Desa Pemulutan Ulu Kab.Ogan Ilir, MK 2019

\begin{tabular}{lcccc}
\hline Varietas & Rata-rata & Inpari 6 & Inpari 33 & Inpari 34 \\
\hline Inpari 6 & 23,3 & - & & \\
Inpari 33 & 24,3 & tn & - & \\
Inpari 34 & 27.5 & $* *$ & tn & tn \\
Situbagendit & 26.2 & $*$ & tn & \\
Rata-rata & 25,3 & & & \\
\hline
\end{tabular}




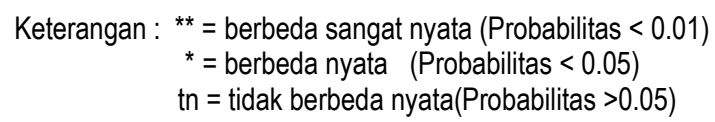

Jumlah gabah per malai

Jumlah gabah per malai dari empat varietas yang dikaji, setelah dianalisis secara statistik menunjukkan tidak berbeda nyata, tetapi secara tabulasi bahwa jumlah gabah terbanyak dicapai oleh Inpari 34 (152,6 butir) dan gabah yang sedikit ditunjukkan oleh Inpari $33(117,4$ butir) (Tabel 4). Jumlah gabah per malai berpengaruh terhadap produksi, jumlah gabah per malai yang tinggi maka produksi tinggi, tetapi sangat dipengaruhi oleh gabah hampa. Bila jumlah gabah hampa tinggi maka produksi gabah akan rendah. Rendahnya gabah hampa bisa diakibatkan oleh serangan hama dan penyakit, kekurangan unsur hara dan air.

Tabel 4. Rata-rata jumlah gabah/malai VUB di Desa Pemulutan Ulu Kab.Ogan llir, MK 2019

\begin{tabular}{lcccc}
\hline Varietas & Rata-rata & Inpari 6 & Inpari 33 & Inpari 34 \\
\hline Inpari 6 & 120.2 & - & & \\
Inpari 33 & 117.4 & tn & - & - \\
Inpari 34 & 152.6 & tn & tn & tn \\
Situbagendit & 132.0 & tn & tn & \\
Rata-rata & 130,5 & & & \\
\hline
\end{tabular}

Keterangan : $\quad$ tn $=$ tidak berbeda nyata(Probabilitas $>0.05$ )

\section{Jumlah gabah isi per malai}

Jumlah gabah isi per malai dari empat varietas yang dikaji, setelah dianalisis secara statistik menunjukkan tidak berbeda nyata, tetapi secara tabulasi bahwa jumlah gabah isi per malai terbanyak dicapai oleh Situbagendit (114,6 butir) dan gabah yang sedikit ditunjukkan oleh Inpari 6 $(104,4$ butir) (Tabel 5). Jumlah gabah isi per malai yang tinggi maka produksi gabah suatu varietas akan tinggi. Dikatakan oleh Utomo dan Widodo (2009) dalam Napitupulu (2015) bahwa jumlah gabah hampa dapat diakibatkan kurangnya distribusi assimilate ke biji dan pemberian hara mikro yang kurang pada tanaman padi.

Tabel 5. Rata-rata jumlah gabah isi/malai VUB di Desa Pemulutan ulu Kab.Ogan Ilir, 2019

\begin{tabular}{lcccc} 
Varietas & Rata-rata & Inpari 6 & Inpari 33 & Inpari 34 \\
\hline Inpari 6 & 104.4 & - & & \\
Inpari 33 & 109.4 & tn & - & - \\
Inpari 34 & 138.4 & tn & tn & th \\
Situbagendit & 114.6 & tn & tn & \\
Rata-rata & 116,7 & & & \\
\hline
\end{tabular}

Keterangan : $t \mathrm{n}=$ tidak berbeda nyata(Probabilitas $>0.05)$

\section{Produksi gabah}

Produksi gabah bervariasi antara 5,4-8,7 ton $\mathrm{GKP} / \mathrm{ha}$ dari empat varietas yang dikaji. Situbagendit mempunyai produksi lebih tinggi yaitu 8,7 ton $\mathrm{GKP} / \mathrm{ha}$, berbeda nyata dengan Inpari 6 , berbeda sangat nyata dengan Inpari 33 dan Inpari 34. Produksi terendah ditunjukkan oleh Inpari 33 yaitu 5,4 ton GKP/ha, berbeda sangat 
nyata dengan Inpari 34 dan Situbagendit (Tabel 6).

Tabel 6. Produksi gabah VUB di Desa Pemulutan Ulu Kab.Ogan Ilir, MK 2019

\begin{tabular}{|c|c|c|c|c|}
\hline Varietas & Rata-rata & Inpari 6 & Inpari 33 & Inpari 34 \\
\hline Inpari 6 & 7,5 & - & & \\
\hline Inpari 33 & 5,4 & ** & - & \\
\hline Inpari 34 & 8,0 & tn & ** & - \\
\hline Situbagendit & 8,7 & * & ** & ** \\
\hline Rata-rata & 7.4 & & & \\
\hline
\end{tabular}

Pada Tabel 6, menunjukkan bahwa produksi varietas Inpari antara 5,4-8,0 ton GKP/ha. Varietas Inpari 34 dan Inpari 6 mempunyai produksi tertinggi yaitu 8,0 ton GKP/ha dan 7,5 ton GKP/ha. Produksi Varietas pembanding Situbagendit lebih tinggi daripada Inpari 6 dan Inpari 34 yaitu 8,7 ton GKP/ha. Bila dilihat dari produksi gabah maka varietas Inpari 6, Inpari 33, Inpari 34 dan Situbagendit dapat beradaptasi dengan baik di rawa lebak. Varietas Situbagendit merupakan varietas padi gogo yang toleran kekeringan sehingga pada saat lahan rawa lebak kekurangan air, varietas tersebut masih dapat memberikan hasil yang baik, apalagi kondisi lahan cukup air maka hasil yang dicapai akan lebih baik. Dede Rohanaya, Robet Asnawi (2012) mengemukakan produksi gabah ditentukan oleh komponen hasilnya dan komponen tersebut ditentukan oleh faktor genetik dari varietas dan faktor lingkungan dimana varietas padi ditanam seperti iklim, hara, tanah dan air. Kemudian Rois et al. (2017), mengatakan hasil gabah dapat dipengaruhi oleh waktu tanam yang efektif, jumlah pupuk, waktu aplikasi dan ketersediaan air. Berdasarkan deskripsi tekstur nasi Inpari 6 (sangat pulen), Inpari 33 (sedang), Inpari 34 (agak pera) dan Situbagendit (pulen) (Jamil et al. 2016).

\section{KESIMPULAN}

Dari uraian diatas dapat disimpulkan bahwa varietas Inpari dan Situbagendit mempunyai tinggi tanaman dengan kriteria pendek, jumlah anakan produktif tergolong banyak dan tidak ada yang rebah. Produksi gabah rata-rata 7,4 ton $\mathrm{GKP} /$ ha dimana produksi gabah tertinggi dicapai oleh Situbagendit $(8,7$ ton GKP/ha) diikuti oleh Inpari 34 (8,0 ton GKP/ha), Inpari 6 (7,5 ton GKP/ha) dan Inpari 33 (5,4 ton GKP/ha). Dengan demikian Varietas tersebut dapat beradaptasi di rawa lebak tengahan dengan produksi gabah baik di Kecamatan Pemulutan Kabupaten Ogan Ilir.

\section{UCAPAN TERIMA KASIH}

Ucapan terima kasih disampaikan kepada teknisi Kebun Percobaan Kayuagung bapak Rajulis, para penyuluh pendamping, kepala BPP Kecamatan Pemulutan Kabupaten Ogan llir bapak Surata dan bapak Yanter Hutapea serta ibu $\mathrm{Hj}$.Harnisah sebagai penanggung jawab kegiatan yang telah memberikan dukungan dalam pelaksanaan kegiatan diseminasi teknologi pertanian sehingga berjalan dengan lancar. 


\section{DAFTAR PUSTAKA}

Abdullah. B, Sularjo, Cahyono dan U. Susanto. 2015. Hasil dan komponen hasil galur harapan padi sawah di dataran sedang, hlm.809-816. Dalam: Satato, P.A.Rumanti, U.Susanto, A. Hairmantis dan P.Sasmita (Ed). Prosiding Seminar Nasional Inovasi Teknologi Padi Mendukung Pertanian Bioindustri. Balai Besar Penelitian Tanaman Padi, Sukamadi, 19 Agustus 2014.

Assad dan Warda. 2011. Keragaan beberapa galur harapan padi sawah di Kabupaten Sidrap Sulawesi Selatan. Dalam : Bambang Suprihatno dkk (ed). Prosiding Seminar IImiah Hasil Penelitian Padi Nasional 2010. Balai Besar Penelitian Padi, Buku 1. Badan Litbang Pertanian Sukamandi. Hal : 77-86.

Dede Rohayana dan R. Asnawi. 2012. Keragaan hasil varietas unggul Inpari 7 , Inpari 10 dan Inpari 13 melalui pendekatan pengelolaan tanaman terpadu (PTT) di Kabupaten Pesawaran. Prosiding inovasi hasil penelitian dan pengkajian teknologi pertanian. BPTP Lampung. Hal.119-128.

Handoko, S, Y.Farmanta dan Adri. 2017. Peningkatan produktivitas padi sawah melalui introduksi varietas unggul baru di Kabupaten Tanjung Jabung Timur Jambi. Di dalam: Sugandi et al (Eds). Prosiding Seminar Nasional Pengkajian Teknologi Spesifik Lokasi Komoditas Tanaman Pangan, Bengkulu. 8 November 2016. p:96-100.
Jamil, A, Satoto, P.Sasmita, Y.Baliadi, A.Guswara dan Suhama. 2016. Deskripsi Varietas Padi. Balai Besar Penelitian Tanaman Padi, Sukamandi.

Manurung, J, Armaini, Idwar. 2017. Uji adaptasi beberapa varietas padi gogo local dan kondisi tegangan air tanah yang berbeda pada bahan tanah Ultisol. JOM Faperta 4 (1):1-15.

Napitupulu, D. 2015. Pengkajian uji adaptasi varietas padi unggul baru Di Kabupaten Tapanuli Selatan Sumatera Utara. Jurnal Pertanian Tropik 2 (3):239-245.

Rois, A.Syukur, Z.Basri. 2017. Uji adaptasi padi unggul Inpara 3 di lahan rawa lebak menggunakan berbagai paket pemupukan adaptif. Jurnal Agroland 24 (3):237-241.

Suparwoto, Rudy Soehendi dan Waluyo. 2013. Kajian usahatani beberapa varietas unggul padi di lahan rawa lebak tengahan Kabupaten Musi Banyuasin Provinsi Sumatera Selatan. Dalam : Achmad Subaidi, Enti Sirnawati, Astrina Yulianti, Yovita A.D, dan Istriningsih (Ed). Prosiding Seminar Nasional Inovasi Pertanian Spesifik Lokasi. Balai Besar Pengkajian dan Pengembangan Teknologi Pertanian, Medan.

Suparwoto, Waluyo dan Harnisah. 2016. Pengembangan budidaya padi di rawa lebak Provinsi Sumatera Selatan, hlm.605614. Dalam: Sugiyarto, H.Perwitasari, L.F.L.Pratiwi, K.Tanjungsari, F.Indana, A.H.Al Rosyid, A.W.Widana, dan W.A.Saputra (Ed). Prosiding Seminar 
Nasional Pengembangan daya saing agribisnis berkelanjutan di era kompetisi global. Fakultas Pertanian Universitas Gajah Mada, Yogyakarta 6 Agustus 2016.

Suparwoto, Susilawati, Yustisia dan A.Azis. 2017. Adaptasi varietas unggul baru di lahan rawa lebak Kabupaten Ogan Komering llir Sumatera Selatan, hlm.518-522. Dalam:B.A.Bahar, R.Jaya, Y.Yusriani, C.N.Herlina, A.Azis, dan R.Hendayana (Ed). Prosiding Seminar Nasional Sinergi Sinkronisasi Program Mendukung Pencapaian Swasembada. Balai Pengkajian Teknologi Pertanian Banda Aceh, 9 Mei 2017.

Suryana. 2016. Potensi dan Peluang Pengembangan Usahatani Terpadu Berbasis Kawasan Di Lahan Rawa. Jurnal Litbang Pertanian 35 (2): 57-68.

Sution. 2017. Keragaan lima varietas unggul baru terhadap pertumbuhan dan produktivitas padi sawah irigasi. Jurnal Pertanian Agros 19 (2):179-185
Waluyo dan Suparwoto. 2014. Peningkatan pendapatan petani dengan tanam jajar legowo di lahan irigasi Kabupaten Ogan Komering Ulu Timur (OKUT), Sumatera Selatan. Jurnal IImu Pertanian AGRIC, Edisi Khusus 2, 26 (3) 2014. Fakultas Pertanian dan bisnis Universitas Kristen Satya Wacana, Salatiga.

Waluyo, Y. Hutapea, dan Suparwoto. 2015. Pengkajian varietas unggul baru padi (Inpari) di lahan sawah tadah hujan, Kabupaten Ogan Komering llir, Provinsi Sumatera Selatan. Prosiding Seminar Nasional 2014. Balai Besar Penelitian Tanaman Padi. Buku 2. Hal. 631-642. Sukamandi, 19 Agustus 2014.

Wibawa, W dan T. Rahman. 2016. Budidaya padi aromatik pada lahan sawah irigasi. Dalam kumpulan makalah litkaji hasil penelitian pengembangan dan penerapan inovasi teknologi pertanian Bengkulu tahun 2015. Seminar diselenggarakan pada Desember 2015 di Bengkulu. p1-9. 